\title{
Substitution of soybean meal for cottonseed meal in multiple supplements for grazing beef heifers in the dry season
}

\section{Substituição do farelo de soja pelo farelo de algodão em suplementos para novilhas de corte sob pastejo durante o período da seca}

\author{
Román Maza Ortega ${ }^{1 *}$; Mário Fonseca Paulino²; Edenio Detmann²; \\ Luciana Navajas Rennó ${ }^{2}$; Lívia de Vieira Barros ${ }^{3}$; Aline Gomes da Silva ${ }^{1}$;

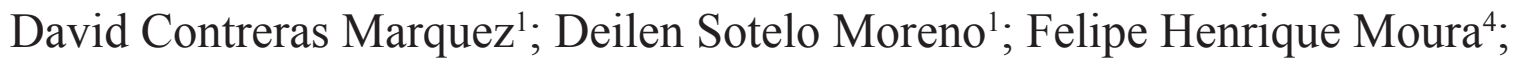 \\ Daniel Mageste de Almeida ${ }^{1}$
}

\begin{abstract}
The objective of this study was to evaluate the effect of substituting soybean meal for cottonseed meal in multiple supplements on the nutritional characteristics and performance of beef heifers in their postweaning phase on Brachiaria decumbens pastures during the dry season. Twenty-four Nellore beef heifers (average initial age and weight of $8 \mathrm{mo}$ and $210 \pm 6 \mathrm{~kg}$, respectively) were used. The design was completely randomized, with four treatments and six replicates. Supplements contained approximately $30 \%$ crude protein $(\mathrm{CP})$ and a progressive substitution of soybean meal for cottonseed meal $(0,50$ and $100 \%$ ). The control animals received only a mineral mixture ad libitum, and those on the other treatments received supplementation at $1.0 \mathrm{~kg} / \mathrm{animal} / \mathrm{day}$. No differences were found in ADG between supplemented and control animals $(\mathrm{P}>0.10)$. Supplementation increased crude protein $(\mathrm{CP})$ intake only $(\mathrm{P}<0.10)$. The level of substitution of soybean meal for cottonseed meal did not affect $(\mathrm{P}>0.10)$ the intake of supplemented animals. Supplementation elevated the apparent digestibility coefficients $(\mathrm{P}<0.10)$ of $\mathrm{OM}, \mathrm{CP}, \mathrm{NFC}$ and TDN, but not EE or NDFap $(\mathrm{P}>0.10)$. A positive linear effect $(\mathrm{P}<0.10)$ of the level of substitution of soybean meal for cottonseed cake was observed on the digestibility of OM, NFC and TDN. Supplementation and the level of substitution had an effect $(\mathrm{P}<0.10)$ on the serum urea nitrogen and urine urea nitrogen contents. Supplementation or substitution level had no effect on the flow of microbial nitrogen to the intestine (MICN) or efficiency of microbial protein synthesis (EMPS) $(\mathrm{P}>0.10)$. Substitution caused a decreasing linear effect $(\mathrm{P}<0.10)$ on microbial nitrogen/nitrogen intake ratio (MICNR). In conclusion, substitution of soybean meal for cottonseed meal in multiple supplements during the dry season does not impair the productive performance of beef heifers.
\end{abstract}

Key words: Braquiaria decumbens, digestibility, intake, supplementation

\section{Resumo}

Objetivou-se avaliar o efeito da substituição do farelo de soja pelo farelo de algodão em suplementos múltiplos sobre as características nutricionais e desempenho produtivo de novilhas de corte em fase

\footnotetext{
${ }^{1}$ Discentes do Curso de Doutorado do Programa de Pós-Graduação em Zootecnia, Universidade Federal de Viçosa, UFV, Viçosa, MG, Brasil. E-mail: rmaza777@hotmail.es; alinezooufv@yahoo.com; davidestebas@hotmail.com; mvzsotelo@hotmail.com; danielmagestedealmeida@hotmail.com

2 Profs., UFV, Viçosa, MG, Brasil. E-mail: mpaulino@ufv.com.br; detmann@ufv.br; lucianarenno@ufv.br

${ }^{3}$ Prof ${ }^{a}$, Universidade Federal de Mato Grosso, UFMT, campus Cuiabá, Brasil. E-mail: liviavieiradbarros@gmail.com

${ }^{4}$ Discente do Curso de Graduação em Zootecnia, UFV, Viçosa, MG, Brasil. E-mail: felipe.moura@ufv.br

* Author for correspondence
} 
de recria em pastagens de Brachiaria decumbens no período da seca. Foram utilizadas 24 novilhas de corte nelore com idade e peso médio inicial de 8 meses e $210 \pm 6 \mathrm{~kg}$, respectivamente. O delineamento foi inteiramente casualizado com quatro tratamentos e seis repetições. Os suplementos continham aproximadamente $30 \%$ de proteína bruta $(\mathrm{PB})$ e substituição progressiva do farelo de soja pelo farelo de algodão em 0, 50 e 100\%. Aos animais do tratamento controle foi fornecida apenas mistura mineral ad libitum e aos demais tratamentos foram fornecidos $1,0 \mathrm{~kg} /$ animal $/$ dia de suplemento. Não houve diferença de GMD entre os animais suplementados e os animais controle $(\mathrm{P}>0,10)$. A suplementação aumentou apenas o consumo de proteína bruta $(\mathrm{PB})(\mathrm{P}<0,10)$. O nível de substituição de farelo de soja pelo farelo de algodão não afetou $(\mathrm{P}>0,10)$ o consumo nos animais suplementados. A suplementação ampliou os coeficientes de digestibilidade aparente $(\mathrm{P}<0,10)$ da $\mathrm{MO}, \mathrm{PB}, \mathrm{CFN}$ e NDT com exceção do EE e da FDNcp $(\mathrm{P}>0,10)$. Observou-se efeito linear positivo $(\mathrm{P}<0,10)$ do nível de substituição de farelo de soja pelo farelo de algodão sobre a digestibilidade da MO, CNF e NDT. Houve efeito da suplementação e do nível de substituição $(\mathrm{P}<0,10)$ sobre o teor de nitrogênio ureico no soro e nitrogênio ureico na urina. Não houve efeito da suplementação e do nível de substituição sobre o fluxo de nitrogênio microbiano ao intestino (NMIC) e eficiência de síntese de proteína microbiana (EFM) $(\mathrm{P}>0,10)$. Foi verificado efeito linear decrescente $(\mathrm{P}<0,10)$ da substituição sobre a relação nitrogênio microbiano/ nitrogênio ingerido (NMICR). Conclui-se que a substituição do farelo de soja pelo farelo de algodão em suplementos múltiplos durante a época seca não prejudica o desempenho produtivo de novilhas de corte.

Palavras-chave: Braquiaria decumbens, consumo, digestibilidade, suplementação

\section{Introduction}

Pastures are the main feeding source used in meat production systems in Brazil, standing out among the other feeding practices due to their low cost of production and high practicality (PAULINO et al., 2006). Cattle in the pre- and post-weaning phases usually receive poor nutrition both in terms of quality and quantity from the forage, which results in a slow growth rate and consequently low productive performance; this ultimately leads to a decrease in the bioeconomic efficiency of the beefcattle-farming activity.

Supplementing grazing cattle has been one of the main strategies to intensify production systems, and it has become essential for the competitiveness and sustainability of the animal husbandry sector (VALADARES FILHO et al., 2006).

In this scenario, due to the high cost of the main protein sources utilized in the formulation of supplements for cattle, such as soybean meal, the use of alternative protein sources can optimize the results, be it through reduction of the production costs without compromising performance, or through the better adequacy of the nutrients available to meet the metabolic requirements of the animal (PINA et al., 2006). As a consequence, researchers have had an increasing interest in the use of cottonseed meal in cattle diets.

Cottonseed meal is an agro-industrial co-product that can replace soybean meal partially or totally in ruminant diets to reduce the use of soybean meal, aiming at more-advantageous economic conditions, despite its lower energy and protein contents. This co-product is characterized by having higher levels of rumen undegradable protein (NRC, 2001; GONÇALVES et al., 2009). The cotton is the second most important source of protein supplement available for animal feeding, only after the soybean (NUVITAL, 2009).

Thus, the objective was to evaluate the effect of substituting soybean meal for cottonseed meal on nutritional characteristics and on productive performance of beef heifers in their post-weaning phase on Bachiaria decumbens pastures during the dry season.

\section{Materials and Methods}

All the procedures performed on the animals had been approved by the Brazilian Committee of 
Ethics in Animal Use and Experimentation.

The experiment was conducted in the Beef Cattle Section of the Animal Science Department of Universidade Federal de Viçosa, located in Viçosa/MG, Brazil, from July to September 2012, which corresponded to the dry season, divided into three 28-day periods. Average temperature and precipitation of $17.7^{\circ} \mathrm{C}$ and $17.6 \mathrm{~mm}$ were observed during the experimental period.

Twenty-four Nellore beef heifers with an initial average age and weight of $8 \mathrm{mo}$ and $210 \pm 6 \mathrm{~kg}$, respectively, were used.

The experimental design was completely randomized, with four treatments, six replicates and three treatments, which consisted of progressive substitution of soybean meal for cottonseed meal $38 \%$ $(0,50$ and $100 \%)$, plus a control group that received a mineral mixture only. The urea:ammonium sulfate (9:1) mix was used to correct the crude protein (CP) contents of the supplements at the substitution levels of 50 and $100 \%$. The multiple supplements were isoproteic, supplied in the amount of $1 \mathrm{~kg} /$ animal/day (Table 1).

Table 1. Supplement composition (\%) on the natural matter basis.

\begin{tabular}{lccc}
\hline \multirow{2}{*}{ Ingredients (\%) } & \multicolumn{3}{c}{ Substitution level $(\mathrm{g} / \mathrm{kg})$} \\
\cline { 2 - 4 } & $\mathrm{CM}_{0}$ & $\mathrm{CM}_{50}$ & $\mathrm{CM}_{100}$ \\
\hline Ground corn grain & 20.80 & 20.80 & 20.80 \\
Ground sorghum grain & 20.40 & 20.40 & 20.40 \\
Soybean meal & 53.80 & 26.90 & - \\
Cottonseed meal & - & 25.72 & 51.44 \\
Mineral mix & & 5.00 & 5.00 \\
Urea/AS (9:1) & 5.00 & 1.18 & 2.36 \\
\hline
\end{tabular}

1/ Centesimal composition: dicalcium phosphate, 50.00; sodium chloride, 47.15; zinc sulfate, 1.50; copper sulfate, 0.75; cobalt sulfate, 0.05 ; potassium iodate, 0.05 and manganese sulfate: 0.05 .

AS - ammonium sulfate.

The animals were weighed at the beginning of the experimental period after a water- and feeddeprivation period of 14 hours aiming to reduce the difference in the filling of the digestive tract. Next, the treatments were distributed randomly to the experimental units (animals).

The supplement was given daily at $10 \mathrm{~h} 00$ during the experiment, in a common trough ( $2 \mathrm{~m}$ length) to allow for simultaneous access of the animals. An experimental area of 8 ha, consisting of four 2-ha paddocks covered uniformly by Brachiaria decumbens grass and provided with drinkers and troughs, was designed for the animals, which were rotated among the paddocks at every seven days to eliminate possible effects of paddocks on the treatments.
To evaluate performance, the animals were weighed at the beginning and end of the experiment, both after a water- and feed-deprivation period of 14 hours, and the weight difference was divided by the number of experimental days (84 days).

The pasture was collected on the fourteenth day of each experimental period to quantify the total availability of dry matter (DM) and potentially digestible dry matter (pdDM), by making a cut close to the soil in four randomly chosen areas within a $0.5 \times 0.5 \mathrm{~m}$ metal frame in each experimental period. After collection, each sample was weighed and homogenized, and a composite sample was made for each paddock. These samples were identified, weighed and immediately taken to a forced air-circulation oven at $60{ }^{\circ} \mathrm{C}$; after 
drying, they were ground in a 1- and 2-mm-sieve knife mill. In these samples the contents of DM were quantified according to INCT-Detmann et al. (2012); neutral detergent fiber (NDF), by following recommendations of Mertens (2002), using thermostable $\alpha$-amylase without sodium sulfide; and indigestible neutral detergent fiber (iNDF), by in situ incubation in F57 (Ankom ${ }^{\circledR}$ ) bags for $288 \mathrm{~h}$, in accordance with Valente et al. (2011).

The pdDM was estimated with the following equation, described for Paulino et al. (2008):

$$
p d D M=0.98 \times(100-N D F)+(N D F-i N D F),
$$

Sampling for qualitative analysis of the pasture consumed by the animals was performed by the hand-plucking method (simulated grazing), every 14 days. This sample was weighed and immediately taken to a forced air-circulation oven at $60{ }^{\circ} \mathrm{C}$ and ground in a knife mill (1 and $2 \mathrm{~mm}$ ). The contents of DM were quantified according to INCT-CA G-003/1, CP according to INCT-CA M-001/1, mineral matter $(\mathrm{MM})$ were quantified according to INCT-CA N-001/1; ether extract (EE) INCTCA G-005/1, neutral detergent fiber (NDF), by following recommendations of INCT-CA F-002/1, using thermostable $\alpha$-amylase without using sodium sulfite; ash- and protein-corrected NDF (NDFap), by following the procedures described by INCTCA M-002/1 and INCT-CA N-004/1, respectively; indigestible neutral detergent fiber (iNDF), after incubation in F57 (Ankom ${ }^{\circledR}$ ) in situ for $288 \mathrm{~h}$, according to Valente et al. (2011); neutral detergent insoluble nitrogen (NDIN).

The non-fibrous carbohydrates (NFC) were quantified according to Hall and Akinyode (2000):

$$
\begin{aligned}
& N F C=100-[(\% C P-\% C P \text { from urea }+\% \\
& \text { urea })+\% N D F a p+\% E E+\% M M],
\end{aligned}
$$

where: NDF $=$ neutral detergent fiber corrected for ash and protein.

To evaluate the nutritional characteristics, a nine-day trial was conducted from the 42 nd day of the experimental period, with six of these days used for the animals to adapt to the markers. To estimate fecal output, $10 \mathrm{~g}$ of the chromium oxide $\left(\mathrm{Cr}_{2} \mathrm{O}_{3}\right)$ were supplied daily, conditioned in paper cartridges, and applied using a metal probe via the esophagus, always at $10 \mathrm{~h} 00$. Titanium dioxide $\left(\mathrm{TiO}_{2}\right)$ was supplied to estimate the individual supplement intake, mixed in the supplement at the proportion of $10 \mathrm{~g} / \mathrm{kg}$ of supplement. To estimate the total DM and pasture DM intakes, iNDF was used as internal marker.

Feces were collected on the last three days of the trial, at different times $(15 \mathrm{~h} 00,11 \mathrm{~h} 00$ and $6 \mathrm{~h} 00$, respectively), aiming to obtain representative fecal samples of each animal. The samples were collected immediately after defecation or directly from the rectum of the animals, in quantities of approximately $200 \mathrm{~g}$; subsequently they were identified per animal and dried in a forced air-circulation oven $\left(60{ }^{\circ} \mathrm{C}\right)$. After drying, they were ground in a knife mill with 1 - and 2-mm sieves.

On the fifth day of the trial, hand-plucking (grazing simulation) was performed individually in each paddock. The samples were used to estimate intake and digestibility coefficients.

A composite sample of feces was made based on the air-dry weight, per animal, for the three collection days. These were stored in plastic labeled jars, and subsequently analyzed for the chromium contents using nitric-perchloric digestion and atomic absorption spectrometry (SOUZA et al., 2013); titanium dioxide, by colorimetry (TITGEMEYER et al., 2001); and DM, CP, EE, NDFap, iNDF and $\mathrm{MM}$, as described previously.

The fecal DM excretion was estimated using the chromic oxide marker, based on the ratio between the amount of marker supplied and its concentration in the feces:

Fecal dry matter (g/day) $=($ Amount of Marker Supplied [g]/Concentration of Marker in Feces $[\%]) \times 100$. 
The individual supplement intake was estimated using the following equation:

$$
I S I=((F D M \times C M F e) / M S G) \times S S G,
$$

where: ISI = individual supplement intake $(\mathrm{kg} /$ day); $\mathrm{CMFe}=$ concentration of marker in the feces $(\mathrm{kg} / \mathrm{kg}) ; \mathrm{MSG}=$ marker present in the supplement supplied to the group ( $\mathrm{kg} /$ day $) ; \mathrm{SSG}=$ supplement supplied to the group ( $\mathrm{kg} /$ day).

Voluntary dry matter intake was estimated by employing iNDF as internal marker, according to the equation

$$
\begin{aligned}
& \text { DMI }(\mathrm{kg} / \mathrm{day})=\{[(F D M \times C M F)-M S] / C M F o\}+ \\
& \text { SDMI, }
\end{aligned}
$$

where: $\mathrm{CMF}=$ concentration of marker in the feces $(\mathrm{kg} / \mathrm{kg})$; CMFo = concentration of marker in the forage $(\mathrm{kg} / \mathrm{kg})$; SDMI = supplement dry matter intake (kg/day); FE = fecal excretion ( $\mathrm{kg} /$ day); and $\mathrm{MS}=$ intake of marker from supplement $(\mathrm{kg})$.

On the last day of the trial, a "spot" sample of urine was collected during spontaneous urination, and of blood via jugular venipuncture, which were performed approximately four hours after the supplement was supplied. After the collection, 10 $\mathrm{mL}$ of urine were diluted in $40 \mathrm{~mL} \mathrm{H}_{2} \mathrm{SO}_{4}(0,036 \mathrm{~N})$ and frozen at $-20{ }^{\circ} \mathrm{C}$ to later quantify the contents of creatinine, urea and purine derivatives. The blood samples were collected at the end of the urine collection period using vacuum tubes containing separator gel and clot accelerator. The blood was immediately centrifuged at $2600 \times g$ for $20 \mathrm{~min}$, and the serum was stored $\left(-20^{\circ} \mathrm{C}\right)$.

The methods to quantify creatinine, uric acid and urea were: kinetic colorimetric, enzymatic colorimetric and fixed-time kinetic, respectively, using an automatic device for biochemistry (Mindray ${ }^{\circledR}$, model BS200E).

The daily urinary volume was calculated from its relationship with the daily excretion of creatinine (EC), adopting the equation proposed by Silva et al. (2012), and its concentration in the spot samples as reference:

$E C(g /$ day $)=0.0345 \times B W^{0.9491}$

where: $\mathrm{BW}=$ body weight.

Analyses of allantoin in the urine were performed as described by George et al. (2006). The total excretion of purine derivatives was calculated as the sum of the amounts of allantoin and uric acid excreted in the urine, both expressed in mmol/day.

The absorbed purines (Y, mmol/day) were calculated from the excretion of purine derivatives (X, mmol/day), by the equation

$$
Y=\left(X-0.385 L W^{0.75}\right) / 0.85
$$

where: 0.85 is the recovery of absorbed purines as purine derivatives, and $0.385 \mathrm{LW}^{0.75}$ is the endogenous contribution to the excretion of purines (BARBOSA et al., 2011).

The ruminal synthesis of nitrogen compounds (Y, g micN/day) was calculated as a function of the absorbed purines (X, mmol/day), using the equation described by Chen and Gomes (1992), except for the purines-N:total-N ratio in the bacteria of 0.134 , according to Valadares et al. (1999):

$$
Y=70 X / 0.83 \times 0.134 \times 1000
$$

where: 70 is the concentration of $\mathrm{N}$ in the purines ( $\mathrm{mg} \mathrm{N} / \mathrm{mol}$ ); 0.134 , the purines-N:total-N ratio in the bacteria; and 0.83 , the digestibility of bacterial purines.

The microbial efficiency was expressed as $\mathrm{g}$ of microbial $\mathrm{CP} / \mathrm{kg}$ digested organic matter ( $\mathrm{g}$ micCP/ $\mathrm{kg}$ DOM).

The results were subjected to analysis of variance, adopting initial body weight as co-variable. The effect of supplementation and the linear and quadratic effects of the level of substitution of soybean meal for cottonseed meal were evaluated by decomposing the sum of squares of treatments using orthogonal contrasts (STEEL et al., 1997). All procedures were conducted using PROC MIXED from SAS (version 9.2). For all statistical procedures 
$\alpha=0.10$ was adopted as critical level of type-I error probability.

\section{Results and Discussion}

In this study, the average DM and pdDM were 5,347 and $3,407 \mathrm{~kg} / \mathrm{ha}$, respectively, with a potential forage digestibility of $63.26 \%$, representing an availability of $179 \mathrm{~g} \mathrm{pdDM} / \mathrm{kg}$ of body weight, which is above the 40 to $60 \mathrm{~g} \mathrm{pdDM} /$ kg BW recommended by Paulino et al. (2004) to exploit the genetic limit of the animal and optimize its performance.

The forage obtained by hand-plucking showed an average CP content of $9.69 \%$ in the DM (Table 2 ), which is above the minimum $7-8 \% \mathrm{CP}$ required in the basal resource to maintain microbial growth and promote an appropriate capacity of degradation of the fibrous substrates of the forage (LAZZARINI et al., 2009; SAMPAIO et al.,
2009), and close to the average protein content of $10 \%$ reported by the aforementioned authors as the level that optimizes the use of energy substrates of the forage.

No difference was observed $(\mathrm{P}>0.10)$ for the average daily gain (ADG) and final body weight of the supplemented animals in relation to those in the control treatment (Table 3). Some factors that might have influenced these results were the high availability of pdDM, the crude protein content of the forage (Table 2) grazed by the animals over the experiment, and the low genetic potential of these animals. This might have allowed for an increased selection of components with a higher nutritional value (DETMANN et al., 2001), elevating the nutritional balance of the animals and reducing the need to use multiple supplements, which can explain the similar performance between the supplemented animals and those that received mineral mixture only. These results contrast with those reported by Barros et al. (2011).

Table 2. Chemical composition of supplements and pasture.

\begin{tabular}{|c|c|c|c|c|c|}
\hline \multirow{2}{*}{ Item $^{1}$} & \multicolumn{3}{|c|}{ Substitution level $(\mathrm{g} / \mathrm{kg})$} & \multirow{2}{*}{ Pasture $^{4}$} & \multirow{2}{*}{ Pasture $^{5}$} \\
\hline & $\mathrm{CM}_{0}$ & $\mathrm{CM}_{50}$ & $\mathrm{CM}_{100}$ & & \\
\hline $\mathrm{DM}(\mathrm{g} / \mathrm{kg})$ & 84.18 & 85.06 & 86.54 & $33.92 \pm 6.14$ & $31.46 \pm 0.73$ \\
\hline $\mathrm{OM}^{2}$ & 91.44 & 90.60 & 92.33 & $92.31 \pm 0.40$ & $92.61 \pm 0.43$ \\
\hline $\mathrm{CP}^{2}$ & 30.83 & 30.82 & 28.42 & $9.39 \pm 1.97$ & $9.69 \pm 0.49$ \\
\hline $\mathrm{NPN}^{3}$ & 11.11 & 26.02 & 36.50 & - & $26.70 \pm 4.23$ \\
\hline $\mathrm{EE}^{2}$ & 1.31 & 0.86 & 1.17 & $1.73 \pm 0.31$ & $2.05 \pm 0.13$ \\
\hline $\mathrm{NDFap}^{2}$ & 18.54 & 20.28 & 28.06 & $57.73 \pm 2.04$ & $55.75 \pm 0.66$ \\
\hline $\mathrm{NDIN}^{3}$ & 24.47 & 31.17 & 35.91 & $58.64 \pm 7.93$ & $51.34 \pm 5.35$ \\
\hline $\mathrm{NFC}^{2}$ & 40.75 & 40.53 & 38.45 & $23.45 \pm 1.52$ & $25.11 \pm 0.46$ \\
\hline $\mathrm{iNDF}^{2}$ & 0.48 & 2.54 & 7.61 & $13.70 \pm 1.83$ & $12.64 \pm 0.46$ \\
\hline
\end{tabular}

1/DM - dry matter; OM - organic matter; CP - crude protein; EE - ether extract; NDFap - neutral detergent fiber corrected for ash and protein; NDIN - neutral detergent insoluble nitrogen; NFC - non-fibrous carbohydrates; iNDF - indigestible neutral detergent fiber. $2 / \mathrm{In} \mathrm{g} / \mathrm{kg} \mathrm{DM} .{ }^{3} / \mathrm{In} \mathrm{g} / \mathrm{kg}$ total nitrogen. ${ }^{4} / \mathrm{Mean}$ values for samples obtained by hand-plucking throughout the experimental period. 5/Mean values for samples obtained by hand-plucking in the digestibility trial. 
Table 3. Adjusted means, standard error (SEM) and indicators of significance for performance of heifers fed the different treatments.

\begin{tabular}{|c|c|c|c|c|c|c|c|c|}
\hline \multirow{2}{*}{ Item } & \multicolumn{4}{|c|}{ Substitution level (g/kg) } & \multirow{2}{*}{ SEM } & \multicolumn{3}{|c|}{ P-value ${ }^{1}$} \\
\hline & Control & $\mathrm{CM}_{0}$ & $\mathrm{CM}_{50}$ & $\mathrm{CM}_{100}$ & & $\mathrm{C} v s \mathrm{~S}$ & $\mathrm{~L}$ & Q \\
\hline ADG (kg) & 0.342 & 0.398 & 0.379 & 0.434 & 0.05 & 0.288 & 0.612 & 0.547 \\
\hline FBW (kg) & 238.80 & 243.60 & 242.00 & 246.60 & 4.14 & 0.285 & 0.613 & 0.547 \\
\hline
\end{tabular}

ADG - average daily gain; FBW - final body weight.

1/C vs S - control versus supplementation; $\mathrm{L}$ and $\mathrm{Q}$ - linear- and quadratic-order effects referring to the substitution levels.

In this study, no effect of supplementation digested organic matter (DOM), digested neutral $(\mathrm{P}>0.10)$ was observed on the voluntary intakes of detergent fiber (DNDF), and TDN (kg/day). The DM, pasture DM, OM, EE, NDFap, NFC, iNDF, exception was CP, whose intake was elevated $(\mathrm{P}<0.10)$ with supplementation (Table 4).

Table 4. Adjusted means, standard error (SEM) and indicators of significance for nutrient intake with the different treatments.

\begin{tabular}{|c|c|c|c|c|c|c|c|c|}
\hline \multirow{2}{*}{ Item } & \multicolumn{4}{|c|}{ Substitution level $(\mathrm{g} / \mathrm{kg})$} & \multirow{2}{*}{ SEM } & \multicolumn{3}{|c|}{ P-value ${ }^{1}$} \\
\hline & Control & $\mathrm{CM}_{0}$ & $\mathrm{CM}_{50}$ & $\mathrm{CM}_{100}$ & & $\mathrm{C} v s \mathrm{~S}$ & $\mathrm{~L}$ & Q \\
\hline \multicolumn{9}{|c|}{$\mathrm{kg} /$ day } \\
\hline $\mathrm{DM}$ & 4.71 & 4.39 & 5.41 & 5.05 & 0.41 & 0.619 & 0.275 & 0.189 \\
\hline PDM & 4.71 & 3.55 & 4.56 & 4.18 & 0.41 & 0.214 & 0.293 & 0.187 \\
\hline SDM & - & 0.84 & 0.85 & 0.87 & - & - & - & - \\
\hline $\mathrm{OM}$ & 4.36 & 4.04 & 5.01 & 4.69 & 0.38 & 0.632 & 0.246 & 0.185 \\
\hline $\mathrm{CP}$ & 0.46 & 0.59 & 0.68 & 0.67 & 0.04 & 0.001 & 0.163 & 0.305 \\
\hline $\mathrm{EE}$ & 0.10 & 0.09 & 0.09 & 0.10 & 0.01 & 0.425 & 0.255 & 0.928 \\
\hline NDFap & 2.62 & 2.15 & 2.75 & 2.54 & 0.23 & 0.615 & 0.239 & 0.171 \\
\hline NFC & 1.18 & 1.21 & 1.50 & 1.40 & 0.10 & 0.122 & 0.215 & 0.148 \\
\hline iNDF & 0.57 & 0.47 & 0.60 & 0.58 & 0.05 & 0.751 & 0.147 & 0.243 \\
\hline DOM & 2.64 & 2.51 & 3.23 & 3.05 & 0.22 & 0.283 & 0.108 & 0.12 \\
\hline DNDF & 1.59 & 1.30 & 1.70 & 1.55 & 0.14 & 0.629 & 0.198 & 0.115 \\
\hline TDN & 2.63 & 2.50 & 3.23 & 3.04 & 0.22 & 0.266 & 0.102 & 0.104 \\
\hline \multicolumn{9}{|c|}{$\mathrm{g} / \mathrm{kg}$ body weight } \\
\hline $\mathrm{DM}$ & 19.50 & 17.70 & 22.00 & 20.00 & 1.64 & 0.784 & 0.388 & 0.148 \\
\hline $\mathrm{OM}$ & 18.00 & 16.50 & 20.40 & 18.60 & 1.52 & 0.797 & 0.348 & 0.143 \\
\hline NDF & 10.80 & 8.80 & 11.20 & 10.10 & 0.92 & 0.448 & 0.332 & 0.136 \\
\hline iNDF & 2.40 & 1.90 & 2.50 & 2.30 & 0.22 & 0.575 & 0.213 & 0.196 \\
\hline
\end{tabular}

DM dry matter, FDM forage dry matter, SDM supplement dry matter, OM organic matter, CP crude protein, EE ether extract, NDFap neutral detergent fibercorrected for ash and protein, NFC non-fibrous carbohydrates, iNDF indigestible neutral detergent fiber, DOM digestible organic matter, DFDN digestible neutral detergent fiber, TDN total digestible nutrients.

1/ C vs S - control versus supplementation; L and Q - linear- and quadratic-order effects referring to the substitution levels. 
The intakes of DM, OM, NDFap and iNDF expressed as $\mathrm{g} / \mathrm{kg}$ body weight were not affected $(\mathrm{P}<0.10)$ by the treatments either (Table 4$)$.

The lack of effect $(\mathrm{P}>0.10)$ on the intakes of pasture DM (PDM), NDFap and iNDF (Table 4) shows that there was no positive associative or substitution effect on intake. In this study, the forage selected by the animals showed a CP concentration above the minimum value established for a proper use of the forage NDF (Table 2), so pasture intake was not restricted; this fact can explain the absence of response to multiple supplementation regarding DM and pasture DM.

The positive effect of supplementation $(\mathrm{P}<0.10)$ on the CP intake $(\mathrm{P}<0.10)$ of the supplemented animals in comparison with the control group is due to the greater density of this nutrient in the supplement in relation to pasture.

No significant effect $(\mathrm{P}>0.10)$ of substitution of soybean meal for cottonseed meal was found in the intake of supplemented animals (Table 4).

For Machado et al. (2011), the digestibility of the diet is a result of the interactive and associative effects of all dietary components rather than just the isolated effect of a certain component.

In this study supplementation elevated $(\mathrm{P}<0.10)$ the apparent digestibility coefficients of DM, OM, CP, NFC and the dietary level of TDN (Table 5), which is probably related to the greater proportion of non-fibrous carbohydrates reducing the representativeness of the fecal metabolic fraction.

Table 5. Adjusted means, standard error (SEM) and indicators of significance for nutrient digestibility with the different treatments.

\begin{tabular}{|c|c|c|c|c|c|c|c|c|}
\hline \multirow{2}{*}{ Item } & \multicolumn{4}{|c|}{ Substitution level $(\mathrm{g} / \mathrm{kg})$} & \multirow{2}{*}{ SEM } & \multicolumn{3}{|c|}{ P-value ${ }^{1}$} \\
\hline & Control & $\mathrm{CM}_{0}$ & $\mathrm{CM}_{50}$ & $\mathrm{CM}_{100}$ & & $\mathrm{C} v s \mathrm{~S}$ & $\mathrm{~L}$ & $\mathrm{Q}$ \\
\hline & & & & $\mathrm{g} / \mathrm{g}$ & & & & \\
\hline $\mathrm{OM}$ & 0.61 & 0.62 & 0.65 & 0.65 & 0.01 & 0.006 & 0.045 & 0.539 \\
\hline $\mathrm{CP}$ & 0.62 & 0.65 & 0.67 & 0.68 & 0.02 & 0.031 & 0.316 & 0.878 \\
\hline $\mathrm{EE}$ & -0.90 & -0.11 & -0.11 & -0.29 & 0.08 & 0.386 & 0.116 & 0.374 \\
\hline NDFap & 0.61 & 0.60 & 0.62 & 0.61 & 0.01 & 0.898 & 0.583 & 0.409 \\
\hline NFC & 0.65 & 0.70 & 0.73 & 0.79 & 0.01 & 0.001 & 0.001 & 0.531 \\
\hline \multicolumn{9}{|c|}{$\mathrm{g} / \mathrm{kg}$ dry matter } \\
\hline TDN & 559.00 & 571.00 & 599.00 & 606.00 & 9.80 & 0.010 & 0.022 & 0.403 \\
\hline
\end{tabular}

OM organic matter, CP crude protein, EE ether extract, NDFap neutral detergent fiber corrected for ash and protein, NFC nonfibrous carbohydrates, TDN total digestible nutrients

1/ C vs S - control versus supplementation; L and Q - linear- and quadratic-order effects referring to the substitution levels.

The increase in the digestibility coefficient of $\mathrm{CP}$ is caused by the higher intake of this nutrient by the animals fed supplement. For Van Soest (1994), the greater nitrogen intake results in progressive reduction of the representativeness of the fecal metabolic fraction of the nitrogen compounds, thereby increasing the total apparent digestibility of CP. This pattern is in accordance with that reported by Barros et al. (2011) and Valadares et al. (1997).

Supplementation did not affect $(\mathrm{P}>0.10)$ the estimates of EE and NDFap digestibility as compared with the animals from control group (Table 5).

However, the digestibility coefficients of $\mathrm{EE}$ observed in this study showed negative values in all 
treatments, due to the low levels of EE intake (from concentrate and forage) by the animals, which was below the fecal metabolic fraction.

Although the cottonseed meal had a higher NDFap content in relation to soybean meal (Table 2), no effect of substitution of soybean meal for cottonseed meal was found in the digestibility coefficient of NDFap ( $\mathrm{P}>0.10$; Table 5).

Substitution of soybean meal for cottonseed meal had an increasing linear effect on the digestibility of DM, OM, NFC and concentration of TDN $(\mathrm{P}<0.10$; Table 5). This is probably due to the result of the interactive and associative effects among the dietary nutrients (DETMANN et al., 2008) and the elevation of the rumen-degradable protein (RDP) content with the inclusion of increasing levels of urea in the supplement. Because it is soluble in the rumen, urea has the advantage of improving the ruminal environment and consequently promoting greater activity of the microbial enzymes, thereby increasing digestibility. These results are similar to those obtained by Costa et al. (2008) and Barros et al. (2011).

No significant effect of substitution of soybean meal for cottonseed meal was found on the digestibility of the other diet components $(\mathrm{P}>0.10$; Table 5).

According to Van Soest (1994), the concentration of urine urea nitrogen (UUN) is positively related to the serum urea nitrogen (SUN) and CP intake. The urea nitrogen in the plasma is employed to diagnose the adequacy of the use of nitrogen compounds in the rumen according to the availability of degradable OM (SAMPAIO et al., 2010).

In this study an effect was observed $(\mathrm{P}<0.10)$ on the concentrations of serum urea nitrogen (SUN) and urine urea nitrogen (UUN) with supplementation (Table 6). These results follow the higher CP intake $(\mathrm{P}<0.10)$ by the supplemented animals in relation to the control treatment (Table 4).

Table 6. Adjusted means, standard error (SEM) and indicators of significance for nitrogen levels with the different treatments.

\begin{tabular}{|c|c|c|c|c|c|c|c|c|}
\hline \multirow{2}{*}{ Item } & \multicolumn{4}{|c|}{ Substitution levels $(\mathrm{g} / \mathrm{kg})$} & \multirow{2}{*}{ SEM } & \multicolumn{3}{|c|}{ P-value ${ }^{1}$} \\
\hline & Control & $\mathrm{CM}_{0}$ & $\mathrm{CM}_{50}$ & $\mathrm{CM}_{100}$ & & $\mathrm{C} v s \mathrm{~S}$ & $\mathrm{~L}$ & $\mathrm{Q}$ \\
\hline MICN (g/day) & 57.80 & 50.60 & 55.10 & 56.00 & 5.76 & 0.566 & 0.516 & 0.804 \\
\hline $\operatorname{MICNR}(\mathrm{g} / \mathrm{g})$ & 0.79 & 0.55 & 0.51 & 0.51 & 0.07 & 0.002 & 0.706 & 0.813 \\
\hline EMPS (g/kg TDN) & 140.70 & 128.90 & 108.90 & 113.00 & 14.15 & 0.160 & 0.439 & 0.497 \\
\hline SUN (mg/dL) & 10.99 & 13.47 & 16.78 & 17.49 & 0.91 & 0.001 & 0.006 & 0.261 \\
\hline UUN (g/day) & 18.40 & 41.70 & 46.60 & 55.30 & 2.79 & 0.001 & 0.003 & 0.574 \\
\hline
\end{tabular}

MICN production of microbial nitrogen compounds grams per day, RMICN, relative microbial nitrogen grms per grams, MEF efficiency of microbial protein synthesis (microbial CP synthesis/DOM intake grams per kilogram), SUN serum urea nitrogen in milligrams per deciliter, UUN urea nitrogen excretion in the urine grams per day.

${ }^{1} / \mathrm{C}$ vs S - control versus supplementation; L and Q - linear- and quadratic-order effects referring to the substitution levels.

The average SUN values in the supplemented and unsupplemented animals were 12.16 and 10.99 $\mathrm{mg} / \mathrm{dL}$, respectively. These values are below the 13.52 and $15.15 \mathrm{mg} / \mathrm{dL}$ plasma urea suggested by Valadares et al. (1997), which correspond to the maximum microbial efficiency that would probably represent the maximum point from which there would be loss of protein in zebu calves fed diets with approximately $62.5 \%$ total digestible nutrients (TDN).

No effect $(\mathrm{P}>0.10)$ of supplementation was found on microbial nitrogen $(\mathrm{MICN})$ or on the 
efficiency of microbial protein synthesis (EMPS); no effect $(\mathrm{P}>0.10)$ of substitution of soybean meal for cottonseed cake was found on these variables either (Table 6). The ruminal availability of energy and nitrogen are the nutritional factors that most affect microbial growth (CLARK et al., 1992). With these results, we can conclude that the requirements of energy and rumen-degradable protein were met, with no limitations to microbial growth. The average EMPS value among the different treatments was $122.9 \mathrm{~g} \mathrm{CP} / \mathrm{kg} \mathrm{DOM}$, which is very close to the $120 \mathrm{~g} \mathrm{CP} / \mathrm{kg}$ DOM recommended by Valadares Filho et al. (2010) for cattle managed under tropical conditions. These results are similar to those reported by Moraes et al. (2009).

The supplemented animals showed a lower MICNR $(\mathrm{P}<0.10)$ as compared with those that received a mineral mixture only (Table 6). This can be attributed to the fact that MICN did not change among the different treatments; however, nitrogen intake increased with supplementation, which results in a decreased MICNR in supplemented animals.

Substitution of soybean meal for cottonseed meal had a positive linear effect $(\mathrm{P}<0.10)$ on the concentrations of SUN and UUN (Table 6). This is likely attributed to the greater proportion of rumen-degradable protein (RDP) with inclusion of the increasing NPN levels in the form of urea:ammonium sulfate (Table 2). The greater concentration of RDP results in an increase in the production of ammonia in the rumen, which causes a reduction in the efficiency of use of rumen ammonia and a consequent increase in SUN and urea losses via urine (SANTOS et al., 2001). Likewise, Figueiras et al. (2010) and Barros et al. (2011) reported an increase in SUN and UUN with inclusion of increasing levels of NPN in the diet.

\section{Conclusions}

The use of multiple supplements does not improve the productive performance of beef heifers on Brachiaria decumbens pastures during the dry season under conditions of high availability of good-quality forage. Substitution of soybean meal for cottonseed meal in multiple supplements does not impair the productive performance of these animals.

The use of multiple supplements increases $\mathrm{CP}$ intake and improves the digestibility coefficient of OM, CP and NFC in beef heifers on Brachiaria decumbens pastures during the dry season. Substitution of soybean meal for cottonseed meal in multiple supplements does not affect nutrient intake; improves the digestibility of $\mathrm{CP}$; and does not affect the use efficiency of dietary nitrogen compounds.

\section{Acknowledgments}

The authors wish to thank the Fundação de Amparo à Pesquisa de Minas Gerais (FAPEMIG) for the financial support.

\section{References}

BARBOSA, A. M.; VALADARES, R. F. D.; VALADARES FILHO, S. C.; PINA, D. S.; DETMANN, E.; LEÃO, M. I. Endogenous fraction and urinary recovery of purine derivatives obtained by different methods in Nellore cattle. Journal of Animal Science, Champaign-IL, v. 89, n. 2, p. 510-519, 2011.

BARROS, L. V.; PAULINO, M. P.; VALADARES FILHO, S. C.; DETMANN, E.; SILVA, F. G. da; VALENTE, É. E. L.; LOPES, S. A.; MARTINS, L. S. Replacement of soybean meal by cottonseed meal 38\% in multiple supplements for grazing beef heifers. Revista Brasileira de Zootecnia, Viçosa, MG, v. 40, n. 4, p. 852859, 2011

CHEN, X. B.; GOMES, M. J. Estimation of microbial protein supply to sheep and cattle based on urinary excretion of purine derivatives - an overview of technical details. Aberdeen: International Feed Research Unit. Rowett Research Institute, 1992. 21 p. (Occasional Publication).

CLARK, J. H.; KLUSMEYER, T. H.; CAMERON, M. R. Microbial protein synthesis and flows of nitrogen fractions to the duodenum of dairy cows. Journal of Dairy Science, Illinois, v. 75, n. 8, p. 2304-2323, 1992. 
COSTA, V. A. C.; DETMANN, E.; VALADARES FILHO, S. C.; PAULINO, M. P.; HENRIQUES, L. T.; MANTOVANI, H. C. In vitro degradation of lowquality tropical forage neutral detergent fiber according to protein and (or) carbohydrates supplementation. Brazilian Journal Animal Science, Viçosa, v. 37, n. 3 p. 494-503, 2008.

DETMANN, E.; PAULINO, M. F.; VALADARES FILHO, S. C. Avaliação nutricional de alimentos ou de dietas? Uma abordagem conceitual. In: SYMPOSIUM INTERNATIONALONBEEF CATTLEPRODUCTION, 2., 2008, Viçosa, MG. Proceedings... Viçosa, MG: UFV, 2008. p. 21-52.

DETMANN, E.; PAULINO, M. F.; ZERVOUDAKIS, J. T.; VALADARES FILHO, S. C.; LANA, R. P.; QUEIROZ, D. S. Suplementação de novilhos mestiços durante a época das águas: parâmetros ingestivos e digestivos. Revista Brasileira de Zootecnia, Viçosa, MG, v. 30, n. 4, p. 1340-1349, 2001.

DETMANN, E.; SOUZA, M. A.; VALADARES FILHO, S. C.; QUEIROZ, A. C.; BERCHIELLI, T. T.; SALIBA, E. O. S.; CABRAL, L. S.; PINA, D. S.; LADEIRA, M. M.; AZEVEDO, J. A. G. Métodos para análise de alimentos. Visconde do Rio Branco: Instituto Nacional de Ciência e Tecnologia de Ciência Animal-INCT, Suprema, 2012. 214 p.

FIGUEIRAS, J. F.; DETMANN, E.; PAULINO, M. F.; VALENTE, T. N. P.; VALADARES FILHO, S. C.; LAZZARINI, I. Intake and digestibility in cattle under grazing during dry season supplemented with nitrogenous compounds. Revista Brasileira de Zootecnia, Viçosa, MG, v. 39, n. 6, p. 1303-1312, 2010.

GEORGE, S. K.; DIPU, M. T.; MEHRA, U. R.; SINGH, P.; VERMA, A. K.; RAMGAOKAR, J. S. Improved HPLC method for the simultaneous determination of allantoin, uric acid and creatinine in cattle urine. Journal of Chromatography B, Short Communication, Izatnagar, v. 832, n. 1, p. 134-137, 2006.

GONÇALVES, L. C.; BOGES, I.; SALES FERREIRA, P. D. Alimentos para gado de leite. In: GONÇALVES, L.C.; BORGES, I.; FERREIRA, P. D. S. (Ed.). Alimentação de gado de leite. Belo Horizonte: FEPMVZ, 2009. p. 381511.

HALL, M. B.; AKINYODE, A. Cottonseed hulls: working with with a novel fiber source. In: ANNUAL FLORIDA RUMINANT NUTRITION SYMPOSIUM, 11., 2000, Gainesville. Proceedings... Gainesville: Florida, 2000, p. 179-186.
LAZZARINI, I.; DETMANN, E.; SAMPAIO, C. B.; PAULINO, M. P.; VALADARES FILHO, S. C.; SOUZA, M. A.; OLIVEIRA, F. A. Intake and digestibility in cattle fed low-quality tropical forage and supplemented with nitrogenous compounds. Revista Brasileira de Zootecnia, Viçosa, MG, v. 38, n. 10, p. 2021-2030, 2009.

MACHADO, P. A. S.; VALADARES FILHO, S. C.; VALADARES, R. F. D.; PAULINO, M. P.; PINA, D. S.; PAIXÃO. M. L. Parâmetros nutricionais e produtivos em bovinos de corte a pasto alimentados com diferentes quantidades de suplemento. Revista Brasileira de Zootecnia, Viçosa, MG, v. 40, n. 6, p. 1303-1312, 2011.

MERTENS, D. R. Gravimetric determination of amylase-treated neutral detergent fiber in feeds with refluxing in beaker or crucibles: collaborative study. Journal of AOAC International, Madison, v. 85, n. 6, p. 1217-1240, 2002.

MORAES, E. H. B. K.; PAULINO, M. F.; MORAES, K. A. K.; VALADARES FILHO, S. C.; ZERVOUDAKIS, J. T.; DETMANN, E. Ureia em suplementos proteicoenergéticos para bovinos de corte durante o período da seca: características nutricionais e ruminais. Revista Brasileira de Zootecnia, Viçosa, MG, v. 38, n. 4, p. 770777, 2009.

NATIONAL RESEARCH COUNCIL - NRC. Nutrients requirements of dairy cattle. $7^{\text {th }}$ ed. Washington: National Academy Press, 2001. 381 p.

NUVITAL. O algodão na nutrição de bovinos. Disponível em http: <//www.nuvital.com.br $>$ Acesso em: 2/2/2009.

PAULINO, M. F.; DETMANN, E.; VALADARES FILHO, S. C. Suplementação animal em pasto: energética ou proteica? In: SYMPOSIUM ON STRATEGIC MANAGEMENT OF PASTURE, 3., 2006, Viçosa, MG. Proceedings... Viçosa, MG: UFV, 2006. p. 359-392.

PAULINO, M. F.; DETMANN, E.; VALENTE, E. E. L. Nutrição de bovinos em pastejo. In: SIMPÓSIO SOBRE MANEJO ESTRATÉGICO DA PASTAGEM, 4., 2008, Viçosa, MG. Anais... Viçosa, MG: UFV, 2008. p. 131169.

PAULINO, M. F.; FIGUEIREDO, D. M.; MORAES, E. H. B. K.; PORTO, M. O.; SALES, M. F. L.; ACEDO, T. S.; VILLELA, S. D. J.; VALADARES FILHO, S. C. Suplementação de bovinos em pastagens: uma visão sistêmica. In: SIMPÓSIO DE PRODUÇÃO DE GADO DE CORTE, 4., 2004, Viçosa, MG. Anais... Viçosa, MG: UFV, 2004. p. 93-139. 
PINA, D. S.; VALADARES FILHO, S. C.; VALADARES, R. F. D.; CAMPOS, J. M. S.; DETMANN, E.; MARCONDES, M. I.; OLIVEIRA, A. S.; TEIXEIRA, R. M. A. Consumo e digestibilidade aparente total dos nutrientes, produção e composição do leite de vacas alimentadas com dietas contendo diferentes fontes de proteína. Revista Brasileira de Zootecnia, Viçosa, MG, v. 35, n. 4, p. 1543-1551, 2006.

SAMPAIO, C. B.; DETMANN, E.; PAULINO, M. F. VALADARES FILHO, S. C. SOUZA, M. A.; LAZZARINI, I.; VEIGA, P.R.P.; QUEIROZ A.C. Intake and digestibility in cattle fed low-quality tropical

forage and supplemented with nitrogenous compounds. Tropical Animal Health and Production, Edinburgh, v. 42, n. 7, p. 1471-1479, 2010.

SAMPAIO, C. B.; DETMANN, E.; LAZZARINI, I.; SOUZA, M. A.; PAULINO, M. F.; VALADARES FILHO, S. C. Rumen dynamics of neutral detergent fiber in cattle fed low-quality tropical forage and supplemented with nitrogenous compounds. Revista Brasileira de Zootecnia, Viçosa, MG, v. 38, n. 3, p. 560569, 2009.

SANTOS, F.; JUCHEM, S.; IMAIZUMI, H. Suplementação de fontes de proteína e de amido com diferentes degradabilidades ruminais para vacas em lactação. Reunião Anual da Sociedade Brasileira de Zootecnia, v. 37, p. 1544, 2001.

SILVA, L. F. C.; VALADARES FILHO, S. C.; CHIZZOTTI, M. L.; ROTTA, P. P.; PRADOS, L. F.; VALADARES, R. F. D.; ZANETTI, D.; BRAGA, J. M. S. Creatinine excretion and relationship with body weight of Nellore cattle. Revista Brasileira de Zootecnia, Viçosa, MG, v. 41, n. 3, p. 807-810, 2012.

SOUZA, N. K. P.; DETMANN, E.; PINA, P. S.; VALADARES FILHO, S. C.; SAMPAIO, C. B.; QUEIROZ, A. C.; VELOSO, C. M. Evaluation of chromium concentration in cattle feces using different acid digestion and spectrophotometric quantification techniques. Arquivo Brasileiro de Medicina Veterinária e Zootecnia, Belo Horizonte, v. 65, n. 5, p. 1472-1482, 2013.
STEEL, R. G. D.; TORRIE, J. H.; DICKEY, D. A. Principles and procedures of statistics. A biometrical approach. $3^{\text {th }}$ ed. New York: McGraw Hill Co, 1997. 666 p.

TITGEMEYER, E. C.; ARMENDARIZ, C. K.; BINDEL, D. J.; GREENWOOD, R. H.; LÖEST, C. A. Evaluation of titanium dioxide as a digestibility marker for cattle. Journal of Animal Science, Champaign, v. 79, n. 4, p. 1059-1063, 2001.

VALADARES FILHO, S. C.; MARCONDES, M. I.; CHIZZOTTI, M. L.; VEIGA, P. R. P. Exigências nutricionais de zebuínos puros e cruzados BR-CORTE. 2. ed. Viçosa: MG, 2010. 193 p.

VALADARES FILHO, S. C.; MORAES, E. H. B. K.; DETMANN, E.; PAULINO, M. P.; VALADARES, R. F. D.; MORAES, K. A. K.; MARCONDES, M. I. Perspectiva do uso de indicadores para estimar o consumo individual de bovinos alimentados em grupo. In: REUNIÃO ANUAL DA SOCIEDADE BRASILEIRA DE ZOOTECNIA, 2006, João Pessoa. Anais... João Pessoa: PB, 2006. v. 43, p. 238-262.

VALADARES, R. F. D.; BRODERICK, G. A.; VALADARES FILHO, S. C.; CLAYTON, M. K. Effect of replacing alfalfa silage with high moisture corn on ruminal protein synthesis estimated from excretion of total purine derivatives. Journal of Dairy Science, Madison, v. 82, n. 11, p. 2686-2696, 1999.

VALADARES, R. F. D.; VALADARES FILHO, S. C.; GONÇALVES, L. C.; VALADARES FILHO, S. C.; SAMPAIO, I. B. M. Níveis de proteína em dietas de bovinos. 4. Concentrações de amônia ruminal e ureia plasmática e excreções de ureia e creatinina. Revista Brasileira de Zootecnia, Viçosa, MG, v. 26, n. 6, p 12701278, 1997.

VALENTE, T. N. P.; DETMANN, E.; QUEIROZ, A. C.; VALADARES FILHO, S. C.; GOMES, D. I.; FIGUEIRAS, J. F. Evaluation of rumen degradation profiles of forages using bags made from different textiles. Revista Brasileira de Zootecnia, Viçosa, MG, v. 40, n. 11, p. 2565-2573, 2011.

VAN SOEST, P. J. Nutritional ecology of the ruminant. $2^{\text {th }}$ ed. London: Comstock Publishing Associates, 1994. $476 \mathrm{p}$. 